\title{
FIFTH GRAVES LECTURE
}

\section{THE ZOONOSES : ANIMALS AS A SOURCE OF HUMAN DISEASE}

\author{
By Fergus J. O’Rourke, M.Sc., Ph.D., M.B., M.R.I.A.
}

$\mathbf{I}$ AM very sensible of the honour which the Roval Academy of Medicine in Ireland and the Medical Research Council of Ireland have conferred on me in selecting me to give this the fifth Graves Lecture. The subject I venture to hope would have interested Robert James Graves for his first paper was about an epidemic of typhus in Galway. " It is said of Graves that one day, whilst visiting the convalescent ward, he remarked the healthy and plump appearance of some of them who had recovered from typhus. Turning to his class, he said, "This is all the effect of our good feeding,' adding ' when I am gone you may be at a loss for an epitaph for me; let me give you one in three words-he fed fevers.', (Cameron, 1916). In 1830 Graves awarded his prize for an essay on typhus to Robert Kane later to become President of Queen's College, Cork (1849) (Fleetwood, 1951).

Virchow (Meyer, 1942) proposed the term zoonosis for animal diseases which are naturally transmissible to man. Subsequent authors have used the word in a variety of senses so that it is necessary to define the term before one begins to discuss the topic. The joint WHO/FAO expert group (WHO, 1959) on zoonoses used a rather wider concept of these diseases than is commonly accepted in that they regarded not alone diseases of animals transferable to man, but also arthropod bites as zoonoses. I propose in this lecture to accept this broad definition.

With many infectious diseases such as malaria, yellow fever, leprosy and tuberculosis now under control it will be agreed generally that the zoonoses are the most significant group of communicable diseases yet to be conquered. The WHO/FAO expert committee in their second report (WHO, 1959) suggested that many zoonoses such as larva migrans, taeniasis and so on should be made notifiable in all countries. I think it is a great pity that this has not been done here. The lack of interest in this group of diseases here was shown when Ireland was one of the few countries not represented at the international congress on zoonoses held in Prague in November, 1963.

Zoonoses hitherto unrecognised are being described with ever increasing frequency and there is little doubt that many remain to be discovered. It is not always realised that all or nearly all communicable diseases had their origin in animals. As the noted Russian parasitologist Pavlovsky (1959) says " the same processes of evolution which lead to speciation of organisms in the course of their adaption to the changing conditions of the external environment are also instrumental in the appearance of various diseases of plants, animals and man". The closer the relationship to man the graver the risk to man's health. Thus most of the infections among the primates pass readily to man.

Many diseases regarded as purely human have in recent years proved to be zoonoses. Viral hepatitis in a form nearly indistinguishable from the purely human disease has been shown by Tareev, Nazaretypan, 
Gemendyaeva and Tareeva (1963) to be transmitted from dogs to man in the Moscow region. These authors suggest that the virus once it reaches man can then be passed directly from man to man.

Indeed the dog acts as a reservoir for many diseases which infect man. The tapeworm Dipylidium caninum is very common in dogs and it occasionally spills over into the human population. Dr. E. P. Kelly of Cobh has given me a specimen taken from a small boy living in a clean house where there were dogs in contact with the children. Professor Kennedy of University College, Galway, sent me a specimen from a child in County Monaghan. These children must have eaten the $\mathrm{dog}$ fleas in order to become infective. During a recent study of the Irish fleas we recorded four dog fleas Ctenocephalides canis on man in a suburb of Cork City (Claassens and O'Rourke, 1965). This infestation occurred in a house where no dog is kept.

Throughout history plague has been a disease which man shares with animals and which originates in either wild or domestic animals. In the ease of wild animal reservoirs of plague contact between man and animal is, as a rule, infrequent with the result that only sporadic cases of human infection occur. For example, a large reservoir of plague (Pasteurella pestis) exists in the rodents of Western North America. Occasional cases of plague occur in boys who shoot such rodents and who contract plague as a result of being bitten by the rodent fleas which rapidly leave the dead host. Further spread from man to man by human fleas is not found in America. However, such a mode of spread is known to occur in some parts of the world where environmental conditions are suitable as, for example, in rural areas of Morocco. The human flea Pulex irritans is found in large numbers during the winter in the seldom-changed clothes of the rural Moroccans. These Pulex borne epidemics are small and limited flaring up suddenly and then dying away. Such man-to-man transmission of bubonic plague by human fleas is rare. As a rule the disease is transmitted to man by rat fleas Xenopsylla from the rodent reservoir. Contact between the wild rodents infected with plague and the peridomestic rat population may be quite frequent. The bacteria can be readily transmitted by the vector from animals to man when conditions are such that rats and man are in close contact. Such conditions existed throughout Europe in the Middle Ages and were responsible for the Black Death, that great pandemic of the XIVth century, in which three-quarters of Europe's population died. Many such epidemics occurred in Europe, 154 in the first 1,720 years of the Christian era (Meyer, 1963). In these epidemics the rodent responsible was Rattus rattus the black rat. The replacement of the black rat by the brown rat Rattus norwegicus is said to be responsible for the disappearance of plague epidemics in Europe. Los Angeles in California had this type of epidemic, dependent on commensal rats, as recently as 1924 when 41 cases, including 34 deaths, occurred (Meyer, 1963). Bewley (1960) refers to the last Irish case, which occurred in Dublin in 1920 . The last epidemic of plague in Ireland occurred in 1650 (Meyer, 1963).

Once Pasteurella pestis has reached the human community there is always the possibility of pneumonic involvement and the danger of droplet dissemination of $P$. pestis. The development of such explosive inter-human infections of pneumonic plague oceurs, for example, in 
Manchuria. There in 1910 tens of thousands of cases occurred between Oetober and March and the epidemic ended in spring. This Manchurian epidemic of pneumonic plague arose from plague among the tarbagans (Arctomys bobac). Among the tarbagans the disease is transmitted by the rodent fleas which are very slow to leave the host. The fleas remain on the dead animals which are brought back to the house and the women are infected when they are bitten by the fleas as they skin the carcass. It appears, however, that such cases are sporadic and that pneumonic plague starts in hunters who handle sick animals (Swellengrebel, 1955).

Plague is an example of a zoonosis which has been brought under control in the last twenty years. A million or more deaths per year in the early years of this century have fallen to a total of little more than two hundred deaths in a year (Anon, 1959).

\section{Arthropod Bites}

The cutaneous reaction produced by the bites or stings of those arthropods that attack man may be due to any one of the following four factors, or to combinations of them : (a) mechanical trauma, '(b) secondary infection, $(c)$ injection of toxic substances, and $(d)$ response to sensitisation. The trauma inflicted by a mosquito bite is small, nevertheless it usually produces typical histological changes in the skin. Gordon and Lumsden (1939) in a classical paper first directed attention to the fact that mosquitoes take up blood either directly from a capillary, or from a pool formed in the tissues by the leakage of blood from capillaries previously lacerated by the mosquitoe's proboscis. The former method was described as " capillary feeding", the latter as " pool feeding". Later we showed in a series of experiments on 75 medical students that there were two peaks on a graph of the number of mosquitoes against the time taken to feed to repletion ( $\mathrm{Tr}$ ). The markedly bimodal distribution of $\mathrm{Tr}$ is we believe caused by capillary feeding (mean time to $\operatorname{Tr} 131 \pm 33$ seconds) and pool feeding (mean time to $\operatorname{Tr} 267 \pm 50$ seconds) (O'Rourke, 1956). Two types of response follow most bites, an immediate reaction beginning either while the arthropod is biting, or shortly afterwards. This consists of a wheal with erythema and pruritis. The delayed reaction begins about 24 hours after the bite and consists of an itchy papule. In experiments with 36 medical students ( $O$ 'Rourke and Murnaghan, 1953) 83 per cent reacted to the bite of Aedes aegypti, although 46 per cent had claimed to be insensitive to mosquito bites. In 64 per cent there was only an immediate reaction and 14 per cent a delayed one, only 6 per cent had both types of reaction. It was found that treatment of the bitten area by an antihistamic cream immediately after biting diminished the severity of the reaction in 60 per cent of cases.

Larrivee et al. (1964) in a histological study of flea bites on the guinea pig describe five stages in the development of sensitivity to bites. In stage one there is no abnormal macroscopic or microscopic change in the skin. Stage two is recognised by the occurrence of delayed skin reactions 24 hours after the bite. Histologically there is intense mononuclear infiltration at the site bitten. The third stage is characterised by both immediate and delayed ( 24 hours) reactions. The former is an eosinophilic infiltration at the site of the bite. The fourth stage occurs when immediate reactivity with eosinophilic infiltration is the sole 
response to a bite. Lastly there is no reaction as a result of desensitisation.

As an example of meehanical damage and probable toxin secretion we may take a case of furuncular myiasis caused by warble fly larva.

\section{Case History}

In early January, 1962, a fine tall farmer aged 38 from the Ballingeary area of West Cork was seen by Dr. Michael Cronin of Macroom. The patient had noticed pain in the right lower quadrant of the abdomen two or three weeks previously. He then developed an indurated, tense, painful, hot swelling on the right lumbar region which persisted for two days. This disappeared and after an interval of a day a new tumour appeared under the left scapula. The patient felt that "something was creeping up" between the scapulae and with it the swelling moved too. Soon a marked tumour was to be seen on the left shoulder above the upper border of the scapula. This swelling disappeared, but after an interval of about 30 hours another appeared in the supraclavicular area. The patient felt ill and nauseated for 12-14 hours before each furuncular lesion developed. The supra. clavicular furuncle increased in size and he went to Dr. Cronin who found an insect larva in the lesion and sent it to Dr. J. Magner who kindly sent the patient and the specimen to me.

The patient was well educated and had noticed what must have been an oesophagitis during the period October to December. When told the larva was that of a warble fly he said that Hypoderma and Gasterophilus were abundant on his farm and that Oestrus ovis did not occur there although much of it was sheep land.

\section{The Warble Fly in Ireland}

T'wo species of Hypoderma occur in Ireland viz. $H$. bovis (L), which according to Carpenter and Steen (1908) is the commoner, and H. lineatum (De Vill) which Carpenter and Steen found was comparatively rare. Kenny and O'Nuallain (1955) in a study of 707 cattle at seven farms in Ireland (location unstaited) found only $H$. bovis.

Infection by the warble fly is still common in Irish cattle, and recently it has been estimated that the loss due to damaged hides alone amounts to $£ 300,000$ per year in the 26 counties of the Republic. The total loss is put at a minimum of $£ 765,000$ (Department of Agriculture, 1964).

\section{Life Cycle of Hypoderma}

The eggs are deposited on the hairs of the skin to which they are firmly cemented by a basal clamp. Up to 800 eggs may be laid by a single female, over half of them within an hour. The eggs are laid in rows of from a few to a dozen or more by $\boldsymbol{H}$. lineatum and singly by $H$. bovis (Scharff, 1950). Neither moisture nor friction is required for the hatehing of the eggs. The larva on emerging from the egg immediately burrows into the skin down a hair follicle.

The migration of the two species through the body differs in the route taken. H. bovis wanders along the nerve trunks through the tissues and may enter the spinal canal via the perineural fat of the nerve roots. If it does so it may eause paralysis by damage either to the nerve or spinal cord or both. H. lineatum, on the other hand, after penetrating the skin makes for the wall of the oesophagus which it penetrates as far as the submucosa giving rise to oesophagitis. It then leaves this organ and, like $H$. bovis, makes for the dorsal region where it cuts a hole through the skin near the spines of the vertebral column. A furuncular pocket or warble is formed there in the connective tissue. The warble is encapsulated by dense fibrous tissue and consists of a chronic granuloma with non-suppurative inflammation (Wolfe, 1950). Some time (about eight weeks) is spent by the larva in the warble where it feeds on 
the exudate. 'The fully grown larva emerges, drops onto the ground, seeks a sheltered spot in the soil, burrows down an inch or two and pupates. The adult emerges from 10 to 80 days later depending on temperature (Scharff, 1950). The complete life cycle takes a year, most of which time is spent in the tissues of the host.

The route of migration, through the tissues, taken by the two species is not, however, completely fixed. Thus, Haberman et al. (1949) removed 982 larvae from 293 infested spinal canals of cattle and found that although 975 were as expected, $H$. bovis, seven proved to be $H$. lineatum.

\section{Human Infestation}

Since man is an abnormal host the larvae often migrate aimlessly in the subcutaneous tissue although the larvae of Gastrophilus, the horse bot, tend to be more superficial and give rise to red larva migrans tracks (James, 1947). Scharff (1950) found no records of Hypoderma completing its larval developmen't in man.

The clinical history in this case suggested that the species involved was $H$. lineatum and on examination the last instar larva indeed proved to be $H$. lineatum. The larva was a well grown one.

This appears to be the second case of furuncular myiasis recorded from Ireland, thus confirming the suggestion I made in 1955 (O'Rourke, 1955) that such cases must occur in Ireland. McCloskey (1957) has reported a very interesting case in which he recorded a penultimate instar larva of $H$. lineatum in an eight year old boy in County Donegal. At one stage the condition simulated blockage of Stenson's duct although McCloskey is not certain that this lesion was due to the larva. Many cases of human infection have been recorded from other parts of the world, and severe pain is a common feature. Complete lower hemiplegia has been recorded in a boy in Montana infected with seven H. lineatum (James, 1947). Fatalities are known to have occurred. Children are more frequently attacked than adults as is often the case with parasites in abnormal hosts.

Scharff (1950) quotes Bishopp et al. (1926) who wrote about the larvae as follows: "They are found usually in the subdermal tissues, where they produce what is often called ' creeping myiasis'. There seems to be a tendeney for the larvae to work upward and most of them are finally extracted from the head, face or upper extremities. These migrations are often extensive and rather rapid, accompanied by considerable pain. In some cases the larvae appear under the mucous membranes of the mouth ".

Scharff (1950) also states that "other descriptions of human myiasis caused by $H$. lineatum and $H$. bovis are given by Henrickson (1921), Engel (1923), Style (1924), Andre (1925), Herms (1925), Lanford and Warner (1925), Lawson (1929), Wegelin (1930), Dos Santos (1932), Pavlovsky and Glezer (1932), Natvig (1935), Smart (1939), and Haseman (1948)."

Ophthalmomyiasis due to Hypoderma also occurs in Ireland (L. E. Werner personal communication) but it has not as yet been recorded in print.

\section{Treatment}

Removal of the larvae is generally all that is required in furuncular myiasis. Systemic treatment has not, to my knowledge, been used in 
man; but, had our patient shown signs of the presence of further warbles, the question of using some of the current parental antiHypoderma insectieides (cf Kahn et al., 1960, and Kahn, 1964) would have had to be considered. Fortunately the patient has remained well.

Ophthalmomyiasis requires surgical intervention.

Clearly myiasis is a condition that should be looked for and it may be expected that myiasis due to Gastrophilus and Oestrus will also be reported from Ireland.

The great group of arbor viruses are represented in Ireland by a member of the B group, namely, one of the louping ill-RSSE virus complex first reported from Ireland by Lickar and Dane (1950). These authors reviewed five human cases of infection, and one of the patients, a medical student, had been bitten by a female Ixodes ricinus (which he kept) at Bundoran, County Donegal, ten days prior to the onset of prodromal symptoms. Serological studies of adolescents with meningoencephalitis in the North of Ireland showed the presence of antibodies to louping ill virus.

The abundance of Ixodes ricinus in Ireland was well illustrated by my report ( $O$ 'Rourke, 1963) that after a day's play in a meadow at Lough Ine, West Cork, three children had 28,23 and 18 larval I. ricinus attached. Even in urban gardens one finds the occasional $I$. ricinus, and I reported that a larval form attached to the lower eyelid of one of my children and presented as a small bluish tumour.

Working in my Department Dr. G. A. Walton (pers. commun.) has investigated a small focus of infection at Ballinagree, eight miles north of Macroom, County Cork. There a hundred acre farm was purchased in 1947 when a flock of 120 sheep were put on the land and 50 died that year. In 1958 cattle replaced sheep but losses were incurred until, in 1959 , the cattle were vaccinated with louping ill vaceine (Welleome). The vaccine gave partial protection to the cattle, which suffered paralysis and convulsions but usually recovered. The nidality of the source of the virus is illustrated by the fact that infection occurred only in the lower half of the farm. Six sentinel sheep were exposed from January 1st to April 30th, 1964. Dr. Carl Eklund of the Rocky Mountain Laboratory of the U.S. Public Health Service isolated viral agent 334-64 from the brain of a sheep sick on April 3rd, 1964. Later viral agent 660-64 was isolated from a pool of female ticks ( $I$. ricinus) collected on a sick lamb born to one of the sentinel sheep. In neutralisation tests using immune sera prepared against English strain of louping-ill virus titre differences of 2.45 and 3.00 respectively were found. This suggests that the Ballinagree virus may be a new variant of louping ill virus.

'Thirteen blood donors' sera were checked for antibody to virus isolate 334-64. Louping antibodies were found in one serum from Millstreet, 12 miles away, and two positive sera were found among donors at the Knocknagree collection centre eight miles away. In all 13 sera were examined. The virus would, therefore, appear to constitute an important danger to public health. Ecologically the area being investigated offers an unique opportunity to study the total ecology of the virus in a location where the animal life is limited to only 11 species of mammal and 26 species of birds, including magpies, known to be reservoirs of central European tick-borne encephalitis (CEE) virus in Slovakia. The possibility of the transportation of the virus by migrant birds cannot be 
outruled. The virus might be carried in the bird, or in ectoparasites on the bird. It is known that the stress of migration ean light up chronic latent infections. This will cause a recurrence of viraemia so that parasites feeding on the bird may pick up the virus and become a local reservoir of infection.

For some years now we have been working on the taxonomic status of Ascaris lumbricoides, the large roundworm of man which occurs not uncommonly here in Ireland. Indeed, it has been recorded as infecting as much as 40 per cent of a County Cork village (Rearden, 1954). The large roundworm of the pig, called $A$. suis, is very common in pigs here in Ireland. The name $A$. suum for the pig Ascaris was proposed in 1782 by Goeze, the human parasite having previously been called A. lumbricoides by Linn'aeus, 1758. The conspecifieity of these two forms was accepted by most authors, and Bakker (1921), in a careful study of the worms, found no morphological differences between the two. The first recorded suggestion that the two might not be identical was made by Koino (1922), who failed to infect a human volunteer with the eggs of $A$. suis but was able to infect man with the eggs of A. lumbricoides. At that time it was not known that, although pigs are frequently naturally infected with Ascaris, it is difficult to infect experimental pigs (Martin, 1926). Payne et al. (1925) supported Koino's findings and showed that $A$. lumbricoides failed to reach maturity in the pig. Takaka (1951) fed two groups of volunteers with eggs of $A$. lumbricoides and $\boldsymbol{A}$ suis. Seven were fed with lumbricoides and all became infected, whereas only seven of the 19 fed with the latter produced infections.

Sprent (1952) claimed that the two forms could be separated on the shape of the dentigerous ridges but the photomicrographs in his paper are anything but convincing although Abdulrachman and Lie Kian (1954) claim to have confirmed Sprent's findings.

Barry and I found that, using a wide variety of chromatographic techniques, no differences could be detected between $A$. suis and A. lumbricoides. Using a wide variety of serological techniques such as Oudin, Ouchterlony, and Consden-Kohn we found that the two forms have many antigens in common and that neither appears to have an antigen that does not oceur in the other. With electrophoresis on cellulose acetate membranes two major and two minor protein fractions were found in both forms of Ascaris. But in the ease of $A$. suum these fractions tended to separate farther than in A. lumbricoides. However, the $A$. suum was obtained alive whereas the lumbricoides reached us about 36 hours after being passed. Kent (1960) also found four active antigens in aqueous extracts. Our conclusions were that no biochemical differences could be found between the two forms of Ascaris. Recent work at the Pavlovsky Institute and at Cambridge is in agreement with our results. Taffs and Voller (1963) in very beautiful fluorescent antibody studies have failed " so far to differentiate the two worms". Lysek (1962) succeeded in infecting himself and regards the two forms as belonging to one species. He states that he "does not think it right to divide this species into two subspecies or varieties. . . This elassification is based on a non-existing specifieity of the hosts and is thus without any justification ".

These results thus place human ascariasis in the eategory of zoonoses. 
The pig is known (Hull, 1963) to carry six viral, 12 bacterial, one spirochaetal, seven fungal, three protozoal, ten helminthic and one arthropod disease. In Ireland one of the protozoal diseases, one spirochaetal and two of the helminth diseases have been recorded. The protozoan in question is Balantidium coli and the ease has been reported by Kennedy and Stewart (1957) who found a 74 per cent infection rate in pigs. The spirochaete is Leptospira icterohaemorrhagiae reported from Irish pigs (Power, 1951) or maybe $L$. canicola which was reported to infect 19 out of 47 piggery workers in Britain (Coghlan et al., 1957). The other nematodal disease occurring in pigs here is Trichinella spiralis (Nash et al., 1957).

During these recent studies in our laboratory on Ascaris, from both pig and man, we encountered two individuals who had developed marked sensitivity to pig Ascaris (Barry and O'Rourke, 1964).

Ransom (1922), who was sensitive to Ascaris, described the classical allergic symptoms vividly, while von Fellenberg (1932) reported that a mother had recurring attacks of urticaria when her son suffered from Ascaris infection. Belding (1938) stated that "supersensitiveness to Ascaris is not uneommon and manifests itself by the usual allergie symptoms of asthma, hay fever, urticaria and eosinophilia. . . . Supersensitiveness is acquired by contact and does not necessarily predicate previous infection."

\section{Clinical Observations}

Patient A had been in contact with Ascaris from the pig for a quarter of a century or more. She noticed an increasing sensitivity in recent years. At first reactions were limited to surface effects e.g. erythema, pruritis and increased lachrymal secretion. Later, despite the fact that the patient took to wearing rubber gloves while dissecting, conjunctival reactions became marked and she noticed the first signs of a respiratory nature. Bronchitis and asthma often followed exposure to Ascaris. At the time we obtained the patient's serum a marked bronchiolar spasm occurred within the hour when Ascaris suum* "was present in the room. The reaction occurred when between 50-80 A. suis were being dissected in a room of seventeen thousand cubie feet.

Patient B on first dissecting a female $A$. suis developed a marked anaphylactic reaction within an hour with severe urticaria, conjunctivitis and spasm of the bronchioles. As he had never experienced such a reaction previously, he was naturally alarmed and reluctant to expose himself again. This patient had previously worked in a pig farm. Although he had not experienced any reaction when working on the farm he must have become sensitised there.

In both cases rapid relief was obtained (within 30 minutes) by the administration of a simple anti-histaminic given orally.

\section{Serological Studies}

We were able to get blood from Patient $A$ but were unable to get blood from Patient B.

Venous blood was allowed to clot and after twelve hours the serum was removed by centrifugalisation. The serum was used at once.

*We will refer to pig ascaris as $A$. suis and the form found in man as $A$. lumbricoides, although our studies to date suggest that these are conspecific. 
Antigens were prepared from both pig and human Ascaris. The following antigens were used :

Antigen 1.-Whole $A$. suum homogenate prepared by homogenising the worms in 0.9 per cent sodium chloride to give a dilution of one gram of tissue per millilitre of solution.

Antigen 2.-Whole $A$. lumbricoides homogenate prepared in the same way.

The human serum gave a positive Ascoli ring test with whole worm homogenate dilutions up to 1 in 500. The Ouchterlony (1949) technique of immunodiffusion in agar gel $(0,8$ per cent) with 1 in 10,000 merthiolate was used in the study of the fresh serum. About $0.25 \mathrm{ml}$. of the serum was placed in the central cup and the Ascaris antigens were placed in the peripheral cups, $7 \mathrm{~mm}$. in diam. The plates were kept at $24^{\circ} \mathrm{C}$. and examined every few hours. A dense zone of precipitate could be seen after 56 hours and a single antigen-ant body reaction oceurred with both the antigens tested. After 72 hours the band of precipitate showed a tendency to split, but even when kept for a few days longer no clear separations occurred. Nor did any further separation occur when the experiments were repeated using 1 in 2 and 1 in 4 dilutions of antigen. As the antigen dilution increased the An $A b$ line became fainter. The lines of precipitate did not cross each other, but the regions of fusion were rather fuzzy so that no elear-cut reaction of identity was obtained. In retrospect it is possible that the cups used were too far apart $(12 \mathrm{~mm}$.) in view of the weakness of the antiserum. Control serum from an adult male exposed to $A$. suum in the laboratory for about five years gave no reaction.

\section{Discussion}

Cireulating precipitating antibodies were shown to be present in a patient sensitive to $A$. suum. These antibodies reacted with both $A$. suum and $A$. lumbricoides antigens to a similar degree and show that this anti-Ascaris serum did not distinguish between the two forms of worm with the Ouchterlony immunodiffusion technique. The antibodies appeared to be weak as reactions could not be obtained if the serum was diluted more than one in four.

Sensitivity to a wide variety of laboratory animals has now been reported, and the subject should be kept under continual review. Apart from reactions to insect and other arthropod "bites" sensitivity to allergens from Blattidae (cockroaches), Culicidae (mosquitoes), Coleoptera, e.g. Tenebreo (meal worms), Cocinellidae (ladybirds), Muscidae (house flies) and Locustidae (locusts) are now well known (Anon., 1962, and O'Rourke, 1955) as are reactions produced by allergens from birds, eats, dogs, guinea pigs, rabbits and many other laboratory animals (Barry and O'Rourke, 1964).

\section{Control}

Prevention of exposure is the best means of control. Where this is not possible protective clothing (rubber gloves and face masks, etc.) will be required. Antihistaminic treatment is of value, but severe cases may require the use of adrenaline. Where sensitivity is extreme a change of occupation may be the only satisfactory method of control. A desensi- 
tising series of injections might be considered as an alternative, but this is a problem for the allergist.

Dogs and, to a lesser degree, cats may act as a reservoir of a wide variety of diseases transmissible to man. Dogs and cats enjoy a much more intimate contact with man than other animals. Not only do they share his dwelling, but sometimes even his bed. Soltys (1958) has shown that cats constitute a minor domestie reservoir of tuberculosis in Britain, where there are six million eats (Burn, 1959). Both eat and dog act as reservoirs of the fungus Microsporum canis which can be passed to children who then may pass the pathogen on to others. The purely human cycle is a self-limiting one for, apparently, the fungus is illadapted to man and loses its infectivity after a few transfers (Kaplan et al., 1958). It may be suggested that $M$. canis is an incipient zoonotic pathogen. The protozoan Toxoplasma gondii may have as high an incidence as 77 per cent in eats and 32 per cent in dogs. There are three million dogs in Britain (Burn, 1959). Lymphocytic choriomeningitis, which is clinically recognised here not infrequently, may be spread from the dog (Armstrong, 1963) although the mouse is a more common source of the virus. So far as I am aware there is no record of a definitive Irish case of this disease (i.e. one with serological confirmation). This is by no means the only virus disease transmissib?e from dogs to man. Measles and mumps can occur in the dog and be spread to man. Dogs should therefore not be allowed to have contact with patients suffering from these diseases. A possible connection between canine distemper and measles was suggested by Adams (1953) and Skaggs (1960) has shown that the viruses of both diseases share identical antigens. The clinical appearance of the two diseases are similar. Dogs are still the most common source of rabies in man throughout the world. Fortunately, in these islands, rabies has been eradicated. In addition to the four viral diseases mentioned Hull (1963) lists five rickettsial, 15 bacterial, two spirochaetal, nine fungal, six protozoal, eleven nematodal, three cestodal, nine trematodal and two arthropod infections that can spread from dogs to man.

The nematodal diseases of the dog are of considerable interest. We have found that Ancylostomum caninum, the dog hookworm, is common in $\operatorname{dog}_{\mathrm{s}}$ in Cork. This nematode is able to pierce the skin and in man it causes cutaneous larva migrans. There seems to be every likelihood that this condition must occur in Ireland although as far as I am aware it has not yet been recorded. The large roundworm of the dog Toxacara canis and to a lesser extent the large roundworm of the cat (Toxacara cati) have been shown to cause visceral larva migrans in man. The most severe damage is caused when the larval worms get into the eye, which then has to be removed. Wilder (1950) reported that when 42 eyes removed from cases first diagnosed on pathological grounds as suffering from pseudogliomata, Coates' disease or endophthalmitis were examined it was found that 24 had been infected with Toxacara and 22 were found to show the granulomatous reaction typical of roundworm infection. Ashton (1960) reported on four cases in Britain where an eyc had been removed for suspected retinoblastoma which were later found to be infected by Toxacara. The histological diagnosis is by no means easy and in one of Professor Ashton's cases 186 sections of the eye had to be examined before the larval worm could be demonstrated. Woodruffe 
et al. (1964) report a further case in Britain, and they point out that infection with the larvae of $T$. canis and $T$. cati is probably much more common than is generally believed. These authors show that in the Home counties of England about 20 per cent of cats and dogs harbour Toxacara. There are no comparable figures for Ireland, but we may assume that human cases must oceur here although to my knowledge no such eases have been published. Although the ocular involvement is the most striking it has been suggested by Woodruffe et al. (1964) that "this predilection may be more apparent than real. If Toxacara larvae should chance to be taken to the eye, then it is likely that they will cause damage which will give rise to symptoms, and these in turn will be followed by operation and a precise histological diagnosis. . . . If, however, the larvae would be taken not to the eye but to the liver, spleen, lungs, muscles, or other organs, they would be unlikely to give rise to any specific symptoms, and on dying they would cause the development of only a small granulomatous focus measuring not more than two or three $\mathrm{mm}$. in diameter and producing no clinically recognisable syndromes ". These authors have devised an intra-dermal test with antigen prepared from adult $T$. canis. When the antigen is used in a dilution of one in a thousand, cross reactions do not seem to occur. Patients having known infections with other helminths, including Ascaris lumbricoides, do not give false positives. Using this intradermal test 35 patients with a history of asthma, urticarial skin eruptions, choroidoretinitis, or otherwise unexplained eosinophilia were tested. Of these 35 no less than 11 gave positive reactions indicating that they had been at some time infested with $T$. canis or $T$. cati.

\section{Acknowledgements}

I should like to thank the Medical Research Council of Ireland for financial support of our studies of Ascaris.

\section{References}

Abdulrachman, S. S. and Lie Kian J. (1954), Docum Med. geogr. trop. 6, 342.

Adams, J. M. (1953), Pediatrics, 11, 15.

Andre, F. (1925), Parasitol, 17, 173.

Anon (1959), Brit. Med. J. 2, 983.

Armstrong, C. (1963), in T. G. Hull "Diseases Transmitted from Animals to Man" Springfield, Illinois.

Ashton, N. (1960), Brit. J. Opthalmol, 44, 129.

Bakker, C. R. (1921), Proefschrift, Leiden.

Barry J. and O'Rourke, F. J. (1964), J. Irish Med. Assoc. j4, 47.

Belding, D. L. (1938), "Textbook of Clinical Parasitology," New York.

Bewley, G. (1960), Irish J. Med. Sci. 6, (409).

Bishopp, F. C., Laake, E. W., Brunbrett, H. M. and Wells, R. W. (1926), U.S. Dept. Agric. Buil. 1369.

Burn, J. C. (1959), Recent Advances in Public Health, 2nd Ed., Churchill, London.

Cameron, C. A., "History of the Royal Collegu of Surgeons in Ireland," Dublin, 1916.

Carpenter, G. H. and Steen, J. W. (1908), J. Dept. Agric. Tech. Instr. Ireland 8, 227.

Claassens, A. J. and O'Rourke, F. J. (1965), Proc. R. Irish Acad. (in press).

Coghlan, J. D., Norvel, J. and Siller, H. S., Brit. Med. J. I., 257.

Dos Santos, R. (1932), Ann. Paras. Human Comp. $9(6), 512$.

Engel, E. O. (1923), Zeitschr. Wess. Insektembiol, Berlin, 18, $\left(\frac{1}{2}\right), 28$.

Fellenberg, J. von (1932), Schweiz med Wschr, 62, (25), 582.

Fleetwood, John, "History of Medicine in Ireland", Dublin, 1951.

Gordon, R. M. and Lumsden, W. H. R. (1939), Ann. Trop. med. Parasit, ?'3, 259.

Haberman, W. O., Morgan, B. B. and Dickie, R. J. (1949), J. agric. Res. 78. 637.

Haseman, L. (1948), J, Econ. Ent, 41, 515.

Henrickson, K. L. (1921), Ent. Meddel, 13, (6), 297.

Herms, W. B. (1925), J. Parasitol, 11, 149.

Hull, T. G. (1963), in "Diseases Transmitted from Animals to Man", Springfield, Illinois. James, M. (1947), "The Flies that Cause Myiasis in Man," U.S. Dэpt. Agric. Publ., 631.

Kahn, M. A. (1964), Canad. Vet. J., 5, (2), 20. 
Kahn, M. A., Connel, R. and Darcel C. Le Q. (1960), Canad. J. Med. 24, 177.

Karpov, S. P. et al. (1958), Qhur. Mikrobiol Epidemiol. Immunol, (Moscow), 24.

Kennedy, C. C. and Stewart, R. C. (1957), Trans, Roy. Soc. Trop. Med. Hyg. 51, (6), 549.

Kenny, J. E. and O'Nuallain, T. O. (1955), Irish Vet. J. 9, (6).

Koino, S. (1922), Jap. Med. World, 2, 317.

Lanford, J. A. and Warner, C. M. (1925), New Orleans Med. \& Surg. J. 77, (11), 473.

Larrivee, D. H., Benjamini, E., Feingold, B. F. and Shimizer, M. (1964), Exp. Parasitol, 15,491 .

Lawson, G. B. (1929), South Med. J. 22, (11), 1003.

Lickar, J. and Dane, A. (1950), Lancet, 1, 456.

Lysek, H. (1962). Ceskoslov Epidemiol Microbiol. Immunol. Prague 10, 134.

Martin, H. M. (1926), Univ. Nebraska Agric. Exp. Stat. Res. Bull., 37.

Meyer, K. (1942), Medicine, Baltimore, 21, 143. (1963), in "Diseases Transmitted from Animals to Man", T. G. Hull, Springfield, Illinois.

McCloskey (1957), J. Irish Med. Assoc. 41, 121.

Nash, J., Kidney, J. G., Furnell, M. and O'Meara, P. (1957), J. Irish Med. Assoc., 40, (237), 74 .

Natvig, L. (1935), "Parasites Transmetteurs, Anim. Venimeux," Moscow.

O'Rourke, F. J. and Murnaghan, M. (1953), J. Allergy, 24, (2), 120.

O'Rourke, F. J. (1955), Ir. J. Med. Sci., 285, 729.

- (1956), Nature, 177, 1087. (1963), Brit. Med. J., 3, 544.

Ouchterlony, O. (1949), Acta path. microbiol scand., 25, 507.

Pavlovsky, E. N. (1959), Proc. $X V$ Int. Congr. London, 1959, 30.

and Glezer, J. (1932), Mag. Paras. Inst. Zool. Acad. Sci., USSR, 3, 103.

Payne, F. M., Ackert, J. E. and Hartman, E. Amer. J. Hyg., 5, 90.

Power, P. N. (1951), Vet. Rec., 63, 156.

Ransom, B. H. (1922), J. Amer. Med. Ass., 79, 1094.

Rearden, J. (1954), Brit. Med. J., 2, 246.

Scharff, D. K. (1950), "Cattle Grubs", Bull 471 Mont. State Coll. Montana.

Skaggs, J. W. (1960), J. Amer, Vet. Med. Ass., 138, 8.

Sprent, J. F. A. (1952), Nature, 170, 627.

Smart, J. (1939), Parasitol, 31, 130.

Soltys, M. A. (1958), Brit. Med. J. (5105), 1133.

Style, F. W. (1924), Brit. Med. J., 3.312, 1086.

Swellengrebel, N. H. (1955), Doc. Med. Geogr. Trop., 7, 182.

Taffs, L. F. and Voller, A. (1963), Trans. R. Soc. Trop. Med. Hyg., 57, 353.

Takaka, T. (1951), Kitasto Arch. Exp. Med., 23, 49.

Wegelin, C. (1930), Jahrb St. Gall Naturev 65, 214.

WHO (1951), "Report on First Session of Joint WHO/FAO Expert Group on Zoonoses," Tech Rep. Series.

WHO (1959), "Second Report of WHO/FAO Expert Group on Zoonoses," Tech. Rep. Series, 169 .

Wilder, H. C. (1950), Trans. Amer. Acad. Opthal. Otolaryng, 55, 99.

Wolfe, L. S. (1950), Canad. J. Anim. Sc., 39, 145.

Woodruffe, A. W., Thacker, C. K. and Shah, A. I. (1964), Brit. Med. J., 1, 1001. 